報 文 2

\title{
ベリリウム，セリウム，ランタン，鉄，白金塩 による分子吸収スペクトル†
}

\author{
大道 寺 英 弘 \\ 東京大学物性研究所 東京都港区六本木（T106）
}

（1980年 4 月 28 日受理）

\begin{abstract}
Molecular Absorption Spectra of Beryllium, Cerium, Lanthanum, Iron, and Platinum Salts ${ }^{\dagger}$
\end{abstract}

Hidehiro DAIDOJI

The Institute for Solid State Physics, The University of Tokyo 7-22-1, Roppongi, Minato-ku. Tokyo 106

(Received April 28, 1980)

\begin{abstract}
The absorption spectra of some salts of beryllium, cerium, lanthanum, iron and platinum in air-acetylene flame were measured in the wavelength range from 200 to $400 \mathrm{~nm}$. A Hitachi 207 type atomic absorption spectrophotometer was used. A deuterium lamp, a home-made continuous radiation lamp and some hollow cathode lamps were used as light sources. The new molecular absorption spectra of cerium, lanthanum and platinum and the absorption spectra due to $\mathrm{Be}(\mathrm{OH})_{2}, \mathrm{LaO}, \mathrm{PtH}, \mathrm{FeO}$ and $\mathrm{FeCl}$ in $200-400 \mathrm{~nm}$ region were obtained. Emission spectra of $\mathrm{CeO}, \mathrm{LaO}$ and $\mathrm{FeOH}$ were also obtained. These molecular absorption bands were estimated as absorption errors of maximum 15 times to the sensitivity of each elements in atomic absorption spectrometry. In addition, spectral line interferences of iron were observed in atomic absorption spectrometry of $\mathrm{Zn}, \mathrm{Cd}, \mathrm{Ni}, \mathrm{Cu}$ and $\mathrm{Cr}$.
\end{abstract}

\section{1. 緒言}

原子吸光分析で微量分析をおこなう祭主成分となる高 濃度の金属塩による吸収が光干涉として問題となる。こ の吸収による干涉は黒鉛炣中においてのみならず普通に 使用している空気ーアセチレン炎中においても生じる.

†原子吸光分析に怙ける光干渉 (IX), (VIII) は大道寺英弘, 分光研究 $29, \quad(1980)$

本報文の一部は分析化学会23年会で講演（1974年11月 2 日, 於大阪)

$\dagger$ Spectral Interferences in Atomic Absorption Spectrometry. (IX)
これまで，空気ーアセチレン炎中で生成する分子化合物 による吸収スペクトルとしてアルカリ金属 ${ }^{1-5)}$ ，アルカ リ土類金属6)-11)，アルミニウム ${ }^{8) 12)-14) ， カ ゙ リ ウ ム ~}{ }^{15)}$,

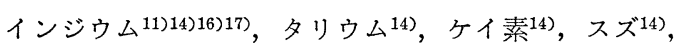
りん酸11)18)-21), 硝酸21), 硫酸321), バナジウム21), ク ロム21)，モリブデン21)，タングステン21)，マンガン21)等 の種々の塩や酸について調べられ，これらの吸収スペク トルによる原子吸光分析のバックグラウンド吸収として の干涉の程度についても報告されている。このような吸 収スペクトルを知ることは原子吸光分析で正しい值を求 める目安となるが，他方では炎中で化学平衡にある生成 分子の種類を知り炎中のラジカルと金属塩との化学反応 
を知ることにつなかっっている．既報て炎中の分子吸収， 原子吸光を測定し原子化効率を求めた ${ }^{15222223)}$. 本報は未 報告のヘリウム，セリウム，ランタン，鉄，白金の塩に ついて 200 400 nm で空気-アセチレン炎中の吸収ス ペクトル抢よひ発光スペクトルを即定し，特に吸収スペ クトルの原子吸光分析にたいする干涉の程度について調 ベた。

\section{2. 試薬および装置}

\section{1 試葉}

標隼容液は㐸のように調製した。ヘリリウム 金属䇴 を塩酸，硝酸によりそれそれ容解した。セりウム 硝酸 セリウム $\left(\mathrm{Ce}\left(\mathrm{NO}_{3}\right)_{3} \quad 6 \mathrm{H}_{2} \mathrm{O}\right)$ を蒸留水により容解した。 ランター 酸化ランタン $\left(\mathrm{La}_{2} \mathrm{O}_{3}\right)$ を塩酸により溶解し た．白金 白金線を塩酸一硝酸により溶解した。鉄。 99 9\%の金属鉄を塩酸，硝酸によりそれそれ容解した。 酸, 試薬は市販の試薬特級を使用し, 蒸留水は脱イオン 水老蒸留して使用した 調製した標隼容液は金属イオン として 10 12 mg/ml を含むもので, 必要時に希釈して 用いた 亜鉛, カトミウム, ニッケル，鉄，マンカン， 銅，クロムの標隼容夜は原子吸光分析に使用したか，こ れらは既報のもの゙)を使用した。

\section{2 㳖置}

日立 207 型原子吸光分光光度計に兵松テレヒ製中空陰 極型重水素ランプ, 試作連続光源, 各種の中空陰極ラン プをとりつけ使用した．炎光発光スペクトルの測定は日 木電子製 JAA 7000 原子吸光/炎光分光分析装置を使用 した.

\section{3. 測 定 方 法}

空気ーアセチレン炎中に 10 又は $12 \mathrm{mg} / \mathrm{ml}$ の金属塩 の溶夜を毎分 $25 \mathrm{ml}$ の割合て噴蓩し, その時得られた 吸光度をアナロク式記録計て記録した。空気流量は 10 1/min，アセチレン流量は $2251 / \mathrm{m} 1 \mathrm{n}$ とした。則定佊長 範囲は 200 400 nm で $05 \mathrm{~nm} こ と に$ 波長を設定して 測定した。スペクトルハント幅は 03 抢よび $18 \mathrm{~nm}$ において，それそれの吸収スペクトルを測定した。吸光 度はスケールの読み (Scale Reading) として表わした 又，発光スペクトルは既報3) と同し方法て求め，金属塩 による発光スペクトルのみを示した。

\section{4. 実験結果および考察}

\section{1 ベリリウム}

ヘリリウム塭酸溶低, 硝酸溶液による吸収スペクトル

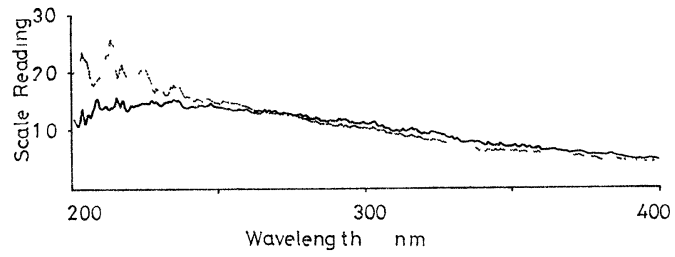

Fig. 1 Absorption spectra obtained by beryllium solutions in arr-acetylene flame

$-\mathrm{Be}-\mathrm{HCl}, \quad \mathrm{Be}-\mathrm{HNO}_{3}, \quad 10 \mathrm{mg} \mathrm{Be} / \mathrm{ml}$,

を Fig 1 に示した。これらのスペクトルは硝酸溶液に よる吸収の方か $200 \sim 260 \mathrm{~nm}$ での $\mathrm{NO}$ や $\mathrm{NO}_{2}$ の吸収 によりわすかに大きいことを除けばほとんど致する. この波長範囲の炎光発光スペクトルを測定したか，本実 験ではどのようなスペクトルも検出されなかった。ベリ リウムの発光スペクトルはアルゴンアーク中や放電管中 て $320 \sim 350 \mathrm{~nm} に \mathrm{BeO}^{2425)}$, $261 \sim 264 \mathrm{~nm} に \mathrm{BeCl}^{26)}$, $347 \sim 367 \mathrm{~nm} に \mathrm{BeCl}^{26) 27)}$ ，か報告されている．また酸

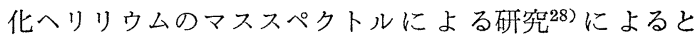
$\mathrm{BeO}$ の蒸気圧は高いか水蒸気を伴う時は $\mathrm{BeO}$ として存 在するよりも $\mathrm{BeOH}$ として存在している。他のアルカ リ土類金属やアルミニウムに関する炎中の重要な反応式 としては次式が知られている.

$$
\begin{aligned}
\mathrm{M}+\mathrm{H}_{2} \mathrm{O} & \rightleftarrows \mathrm{MOH}+\mathrm{H} \\
\mathrm{MOH}+\mathrm{H}_{2} \mathrm{O} & \rightleftarrows \mathrm{M}(\mathrm{OH})_{2}+\mathrm{H}
\end{aligned}
$$

(1)，(2) から（3）か得られる.酸化物は（4) 式から得ら れる。

$$
\begin{aligned}
& \mathrm{M}+2 \mathrm{H}_{2} \mathrm{O} \rightleftarrows \mathrm{M}(\mathrm{OH})_{2}+2 \mathrm{H} \\
& \mathrm{M}+\mathrm{OH} \rightleftarrows \mathrm{MO}+\mathrm{H}
\end{aligned}
$$

この反応式により解離平衡を求め, 炎中の解離原子 $\mathrm{M}$ に対する一水酸化物, 二水酸化物, 酸化物の割合 $(\mathrm{MOH} /$

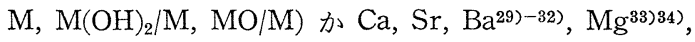
$\mathrm{A}^{35)}$ について計算され原子化効率か求妨らている. ヘリリウムについても一酸化二窒素－アセチレン炎を使 用して求められている ${ }^{36)}$. それによると炎中のへリリウ 厶化合物の $70 \sim 90 \%$ は $\mathrm{Be}(\mathrm{OH})_{2}$ であり, $1 \sim 2 \%$ は $\mathrm{BeO}$, 残りの $30 \sim 10 \%$ か $\mathrm{BeOH}$ として存在する. 空気ーアセ チレン炎中でヘリリウムはほとんど原子化して抢らず (原子化効率は $4 \times 10^{-5}$ 37) $), \mathrm{BeO}, \mathrm{BeCl}$ なとによる発光 スペクトル打よひ财収スペクトルか検出されないことな どから，200〜400 nm の吸収スペクトルは他のアルカリ 土類金属 ${ }^{9110}$ やアルミニウム ${ }^{14)}$ の場合と同様に二水酸化 物・ $\mathrm{Be}(\mathrm{OH})_{2}$ によるものと推定される。この吸収スペク トルの吸収強度は他のアルカリ土類金属の 200〜 400 nm に打ける吸収強度と同椂，少燃料炎で大きく多燃料炎に するにつれて减少する. 炎の上部て吸収は大きいか，こ 
れは炎の上部程 $\mathrm{H}$ ラジカルに比へて密度の高い $\mathrm{H}_{2} \mathrm{O}$ と の反応生成物であることを示している38).むし $\mathrm{BeOH}$ であるならば他の $\mathrm{CaOH}^{9)}$ や $\mathrm{SrOH}, \mathrm{BaOH}^{10)}$ のように もっと幅の狭い帯スペクトルが得られるに違いないから である. 又, Be-O の解離エネルギーは $106 \mathrm{Kcal} / \mathrm{mol}^{28)}$ であるので $\mathrm{Ca}-\mathrm{O}$ や $\mathrm{Sr}-\mathrm{O}$ の解離エネルギーと同程度 である。もし炎中で $\mathrm{BeO}$ の存在割合が高ければカルシ ウムやストロンチウムのように 5 10\%程度は空気ーア セチレン炎中で原子化するものと考えられる.

\section{2 セリウム}

硝酸セリウムによる吸収スペクトルを Fig. 2 に示し たが強い吸収は得られなかった。硝酸による $\mathrm{NO}, \mathrm{NO}_{2}$ の吸収が $200 \sim 260 \mathrm{~nm}$ に検出された. 炎光発光スペク トルは $200 〜 330 \mathrm{~nm}$ でほとんど得られなかったが，

Fig. 3 に示したように $480 \mathrm{~nm}$ を極大とする帯スペク トルが, 330〜 $520 \mathrm{~nm}$ の範囲に得られた。この極大波長

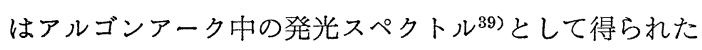
$\mathrm{CeO}$ の分子スペクトルと一致する. $461.4 \mathrm{~nm}(1,0) \mathrm{D}$ 系, $468.3 \mathrm{~nm}(1,0) \mathrm{E}$ 系， $479.1 \mathrm{~nm}(0,0) \mathrm{D}$ 系，扰よび $486.3 \mathrm{~nm}(0,0) \mathrm{E}$ 系がピークとして検出できた. 一酸化 二窒素ーアセチレン炎中ではこの带スペクトルが弱い発 光スペクトルとして報告されている(0). Ce-O の解離エ

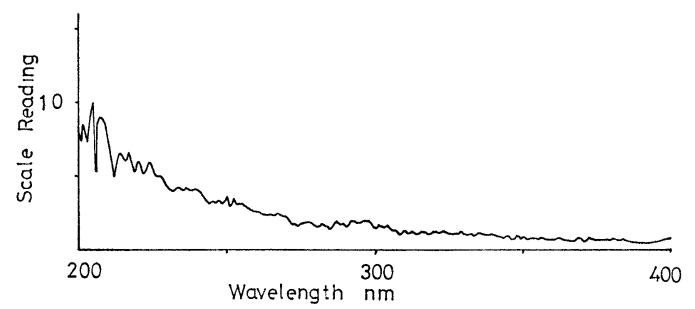

Fig. 2. Absorption spectrum obtained by cerium nitrate solution in arr-acetylene flame. $10 \mathrm{mg} \mathrm{Ce} / \mathrm{ml}$,

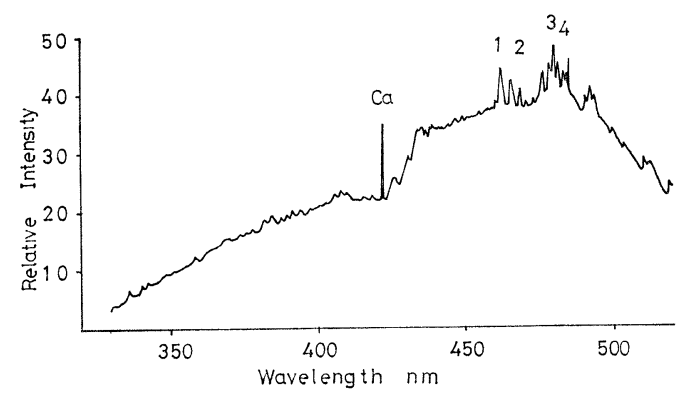

Fig. 3. Emission spectrum obtained by cerium nitrate solution in air-acetylene flame.

$\mathrm{CeO}$ bands. $1: 461.4 \mathrm{~nm}(1,0) \mathrm{D}, \quad 2: 468.3 \mathrm{~nm}(1,0)$ E, $3: 479.1 \mathrm{~nm}(0,0) \mathrm{D}, \quad 4: 486.3 \mathrm{~nm}(0,0) \mathrm{E}$,
ネルギーは 18542) 19141) $\mathrm{Kcal} / \mathrm{mol}$ と高い. 又, セリ ウムは $\mathrm{CeO}_{2}$ を作る ${ }^{43)} .200 \sim 400 \mathrm{~nm}$ の吸収は $\mathrm{CeO}_{2}$ に よるものか，他の安定な化合物によるものか明らかでな W.

\section{3 ランタン}

ランタンの高檂度溶液はストロンチウムと共にマグネ シウムやカルシウムに対するりん酸の化学干渉の除去等 に用いられる. F1g. 4 に示したように200〜400nm にラ ンタンによる吸収スペクトルが得られた。この四収スペ クトルのピークは $212,243,297,360 \mathrm{~nm}$ 付近に認めら れたが, 発光スペクトルびは (F1g. 5) $360 \mathrm{~nm}$ 付近にのみ

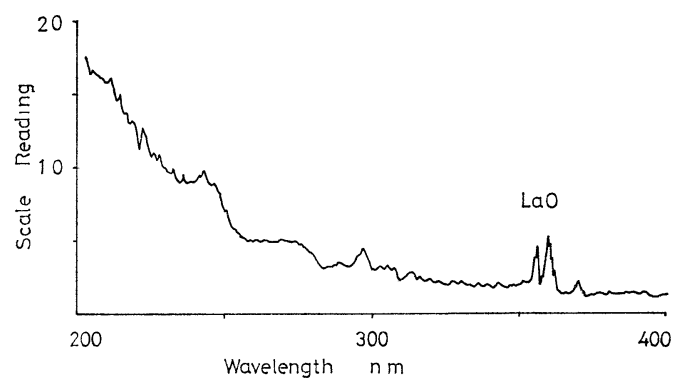

Fig. 4. Absorption spectrum obtained by lanthanum solution containing $\mathrm{HCl}$ in arr-acetylene flame. $10 \mathrm{mg} \mathrm{La} / \mathrm{ml}$,

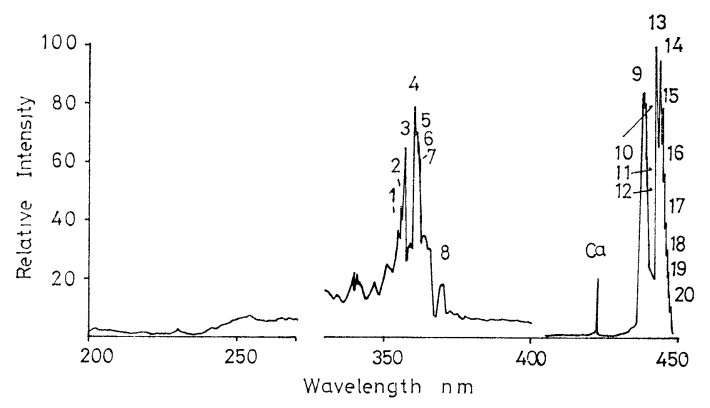

Fig. 5. Emission spectrum obtained by lanthanum solution in arr-acetylene flame.

LaO bands: 1-3: (F $\left.\mathrm{F}^{2} \Sigma-\mathrm{X}^{2} \Sigma\right), \quad 4-7:\left(\mathrm{D}^{2} \Sigma-\mathrm{X}^{2} \Sigma\right)$ system, 1: $355.6 \mathrm{~nm}(2,2), \quad 2: 356.1 \mathrm{~nm}(1,1)$, 3: $356.6 \mathrm{~nm}(0,0), \quad 4: 360.4 \mathrm{~nm}(0,0), \quad 5: 360.8$ $\mathrm{nm}(1,1), \quad 6: 361.1 \mathrm{~nm}(2,2), \quad 7: 361.5 \mathrm{~nm}(3,3)$, 8: $371.0 \mathrm{~nm}(?)$

LaO bands : 9-12: ( $\left.\left.\mathrm{C}^{2} \Pi_{1} \frac{1}{2}-\mathrm{X}^{4} \Sigma\right), 13-20: \mathrm{C}^{2} \Pi_{0} \frac{1}{2}-\mathrm{X}^{4} \Sigma\right)$ system, 9: $437.2 \mathrm{~nm}(0,0), \quad 10: 437.6 \mathrm{~nm}(1,1)$, 11: $438.0 \mathrm{~nm}(2,2), \quad 12: 438.4 \mathrm{~nm}(3,3)$, 13: $441.8 \mathrm{~nm}(0,0), 14: 442.3 \mathrm{~nm}(1,1)$, 15: $442.8 \mathrm{~nm}(2,2), \quad 16: 443.3 \mathrm{~nm}(3,3)$, $17: 443.8 \mathrm{~nm}(4,4), \quad 18: 444.3 \mathrm{~nm}(5,5)$, 19: $444.8 \mathrm{~nm}(6,6), \quad 20: 145.3 \mathrm{~nm}(7,7)$, 
吸収スペクトルに相当する発光スペクトルを得たが 212 , $243,297 \mathrm{~nm}$ 付近では検出されなかった。この $360 \mathrm{~nm}$ 付近のスペクトルは $\mathrm{LaO}$ にるもので $355.6 \mathrm{~nm}(2,2)$, $356.1 \mathrm{~nm}(1,1), 356.6 \mathrm{~nm}(0,0)$ の $\left(\mathrm{F}^{2} \Sigma-\mathrm{X}^{2} \Sigma\right)$ 系のスペ クトル, $3604 \mathrm{~nm}(0,0), 360.8 \mathrm{~nm}(1,1), 361.1 \mathrm{~nm}(2,2)$, $361.5 \mathrm{~nm}(3,3), 366.0 \mathrm{~nm}(2,3), 371.0 \mathrm{~nm}\left({ }^{2}\right)$ の ( $\mathrm{D}^{2 \Sigma}$ $\mathrm{X}^{2 \Sigma)}$ 系スペクトル27)である. また本奏験でこの他に $\mathrm{LaO}$ の発光スペクトルとして，442 $\mathrm{nm}$ 付近に 437.2 $\mathrm{nm}(0,0), 437.6 \mathrm{~nm}(1,1), 438.0 \mathrm{~nm}(2,2), 438.4 \mathrm{~nm}(3,3)$ などの $\left(\mathrm{C}^{2} \Pi_{1 \frac{1}{2}}-\mathrm{X}^{4} \Sigma\right)$ 系スペクトル 27$), 441.8 \mathrm{~nm}(0,0)$, $442.3 \mathrm{~nm}(1,1), 442.8 \mathrm{~nm}(2,2), 443.3 \mathrm{~nm}(3,3), 443.8$ $\mathrm{nm}(4,4), 444.3 \mathrm{~nm}(5,5), 444.8 \mathrm{~nm}(6,6), 4453 \mathrm{~nm}(7,7)$ などの $\left(\mathrm{C}^{2} \Pi_{0} \frac{1}{2}-\mathrm{X}^{4} \Sigma\right)$ 系スペクトル ${ }^{27)}, 560.2 \mathrm{~nm}$ 付近に $\left(\mathrm{B}^{2} \Sigma-\mathrm{X}^{4} \Sigma\right)$ 系スペクトル ${ }^{27)}, 740.3 \mathrm{~nm}$ 付近に $\left(\mathrm{A}^{2} \Pi_{1 \frac{1}{2}}\right.$

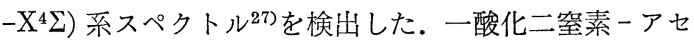
チレン炎40)，酸素 - 水素炎45) ルが報告されている. La一O の解難エネルギーは 181 〜 $188 \mathrm{Kcal} / \mathrm{mole}^{41) 43) 46)}$ と高く非常に安定である. 炎中 のランタンに対する他の反応生成物について他に報告が なく $\mathrm{LaO}$ を除く他の吸収スペクトルについては説明で きない。

\section{4 白金}

白金の溶液による吸収スペクトルをFig. 6 に示した。 白金の溶液も硝酸を含むため $\mathrm{NO}, \mathrm{NO}_{2}$ を伴う吸収スペ クトルが得られた。吸収スペクトルに $354.6 \mathrm{~nm}(1,0)$, $375.2 \mathrm{~nm}(0,0)$ に $\mathrm{PtH}$ の $\left(\mathrm{B}^{2} \Delta_{5 / 2}-\mathrm{X}^{2} \Delta_{5 / 2}\right)$ 系のスペクト ルのピークを検出した. しかし，報告されているような $\mathrm{PtC}^{27)}$ の発光スペクトルは検出されなかった. 他に $\mathrm{PtO}^{48)}$ や $\mathrm{PtO}_{2}{ }^{44)}$ を生成することが知られているが本実 験では検出できなかった。

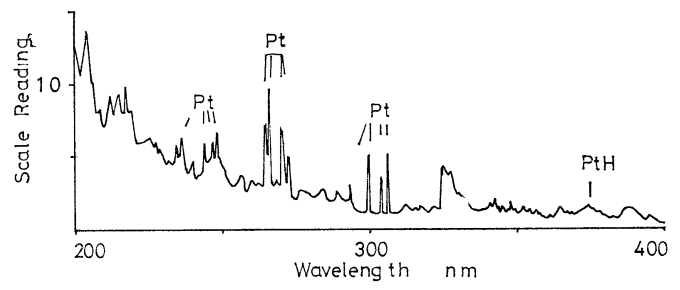

F1g. 6. Absorption spectrum obtained by plat1num solution in air-acetylene flame. $10 \mathrm{mg} \mathrm{Pt} / \mathrm{ml}$

\section{5 铁}

塩酸溶液による吸収スペクトルを F1g. 7 に示した。 鉄については多くの原子線による吸収スペクトル，発光 スペクトルが得られるが，これらの線スペクトルに重な って $\mathrm{FeCl}, \mathrm{FeO}$ の吸収スペクトル, $\mathrm{FeOH}$ の発光スペ

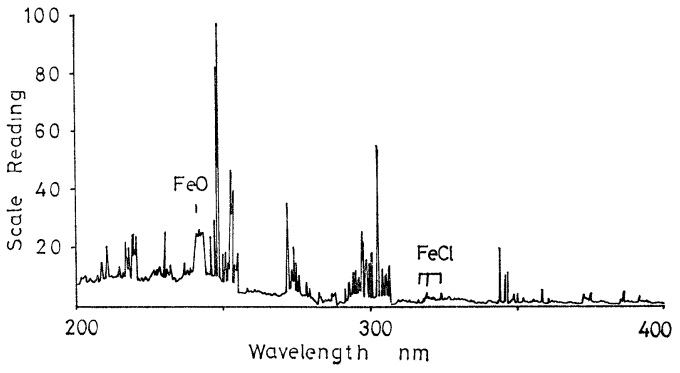

F1g. 7. Absorption spectrum obtained by iron solution in air-acetylene flame. $10 \mathrm{mg} \mathrm{Fe} / \mathrm{ml}$

クトルが検出された. $\mathrm{FeCl}$ のスペクトルは $315.7 \mathrm{~nm}$ $(1,0), 319.9 \mathrm{~nm}(0.0)$ および $324.4 \mathrm{~nm}(0.1)$ の $\alpha$ スペ クトル ${ }^{27)}$ が得られたが放電管中で発光スペクトルとして 報告されている 337〜342 nm および 351〜363 nm の $\mathrm{FeCl}$ の吸収スペクトルは検出されなかった。 又, 241〜 $243 \mathrm{~nm}$ に $\mathrm{FeO}$ のスペクトル ${ }^{49)}$ が吸収スペクトルとし て検出された. $\mathrm{FeOH}$ の $353 \sim 358 \mathrm{~nm}$ および 363〜 $368 \mathrm{~nm}$ のスペクトルは吸収スペクトルとしてほとんど 検出されないが発光スペクトルとしては線スペクトルに 重なって得られた。これらの鉄の化合物の解難エネルギ 一は比較的小さいので空気ーアセチレン炎程度の温度て も原子状態となりやすい。

Table I. Spectral overlaps of iron atomic lines found in atomic absorption of $\mathrm{Zn}, \mathrm{Cd}, \mathrm{N}_{1}$, $\mathrm{Mn}, \mathrm{Cu}$ and $\mathrm{Cr}$.

\begin{tabular}{c|c|c|c}
\hline \hline analyte & $\begin{array}{c}\text { wavelength } \\
\mathrm{nm}\end{array}$ & $\begin{array}{c}\text { 1nterfering } \\
\text { wavelength } \\
\text { of 1ron line } \\
\mathrm{nm}\end{array}$ & $\begin{array}{c}\text { separation } \\
\mathrm{nm}\end{array}$ \\
\hline $\mathrm{Zn}$ & 213.856 & 213.859 & 0.003 \\
$\mathrm{Cd}$ & 228.802 & 228.763 & 0.039 \\
$\mathrm{N1}$ & 232.003 & 231.977 & 0.026 \\
& & 232.037 & 0.034 \\
$\mathrm{Mn}$ & 279.482 & 279.501 & 0.019 \\
& & 279.470 & 0.012 \\
$\mathrm{Cu}$ & 324.754 & 324.721 & 0.033 \\
& & 324.821 & 0.067 \\
$\mathrm{Cr}$ & 357.869 & 357.838 & 0.031 \\
\hline
\end{tabular}

\section{6 吸収強度と干渉誤差}

F1g. 8 にベリリウム，白金，鉄，F1g. 9 にセリウム, ランタンについて濃度と吸光度の関係を示したが，いず れの元素についてもほほ直線となった. 測定波長によっ てその傾きは異なるが濃度を増すにつれて吸光度は増加 した。ベリリウムは測定波長を変えてもその傾きに大き 


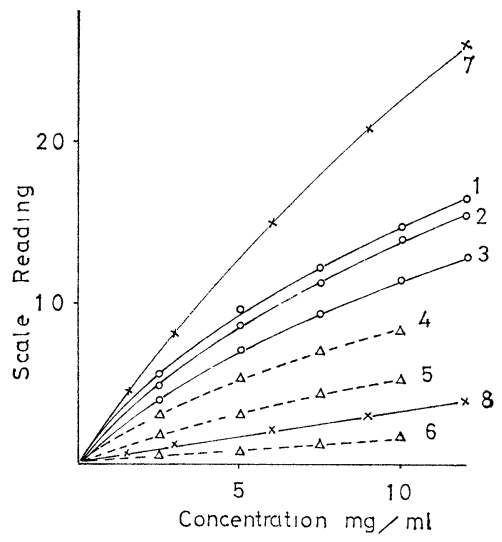

Fig. 8. The relation between absorbances at each band and the concentrations of $\mathrm{Be}, \mathrm{Pt}$ and Fe.

1: Be, $232.0 \mathrm{~nm}, \quad 2: \mathrm{Be}, 213.9 \mathrm{~nm}, \quad 3: \mathrm{Be}, 324.7$ $\mathrm{nm}, 4: \mathrm{Pt}, 213.9 \mathrm{~nm}, 5: \mathrm{Pt}, 232.0 \mathrm{~nm}, 6: \mathrm{Pt}$, $324.7 \mathrm{~nm}, 7: \mathrm{Fe}, 240.7 \mathrm{~nm}, 8: \mathrm{Fe}, 324.7 \mathrm{~nm}$,

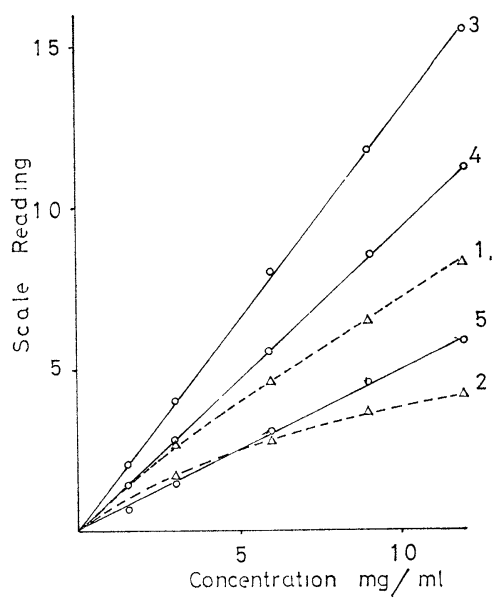

Fig. 9. The relation between absorbances and the concentrations of $\mathrm{Ce}$ and $\mathrm{La}$.

1: Ce, $213.9 \mathrm{~nm}, \quad 2: \mathrm{Ce}, 240.7 \mathrm{~nm}, \quad 3: \mathrm{La}, 213.9$ $\mathrm{nm}, \quad 4: \mathrm{La}, 232.0 \mathrm{~nm}, 5: \mathrm{La}, 285.2 \mathrm{~nm}$,

Table II. Interferences of molecular absorption of some metal salts in atomic absorption spectrometry of $\mathrm{Zn}, \mathrm{Cd}, \mathrm{N}_{1}, \mathrm{Fe}, \mathrm{Mn}, \mathrm{Cu}$ and $\mathrm{Cr}$.

\begin{tabular}{|c|c|c|c|c|c|c|c|}
\hline \multirow{2}{*}{ analyte } & \multirow{2}{*}{$\begin{array}{c}\text { wavelength } \\
\mathrm{nm}\end{array}$} & \multirow{2}{*}{$\begin{array}{c}\text { sensitivity } \\
\mu \mathrm{g} / \mathrm{ml}\end{array}$} & \multicolumn{5}{|c|}{ error by molecular absorption $\mu \mathrm{g} / \mathrm{ml}$} \\
\hline & & & $\mathrm{Be}$ & $\mathrm{Ce}$ & $\mathrm{La}$ & $\mathrm{Fe}$ & $\mathrm{Pt}$ \\
\hline $\mathrm{Zn}$ & 213.9 & 0.005 & 0.065 & 0.044 & 0.075 & 0.087 & 0.040 \\
\hline $\mathrm{Cd}$ & 228.8 & 0.005 & 0.047 & 0.022 & 0.052 & 0.065 & 0.025 \\
\hline $\mathrm{Ni}$ & 232.0 & 0.029 & 0.27 & 0.10 & 0.28 & 0.34 & 0.14 \\
\hline $\mathrm{Fe}$ & 248.3 & 0.022 & 0.25 & 0.06 & 0.12 & $\ldots \ldots$ & 0.13 \\
\hline $\mathrm{Mn}$ & 279.5 & 0.012 & 0.10 & 0.03 & 0.06 & 0.06 & 0.032 \\
\hline $\mathrm{Cu}$ & 324.7 & 0.017 & 0.16 & 0.015 & 0.03 & 0.067 & 0.05 \\
\hline $\mathrm{Cr}$ & 357.9 & 0.12 & 0.75 & 0.09 & 0.30 & 0.85 & 0.12 \\
\hline
\end{tabular}

* Pt, Be, Ce, La and Fe: $10 \mathrm{mg} / \mathrm{ml}$, air-acetylene flame

な変化はないが，鉄，ランタンについてはその差が大き い. $\mathrm{FeO}$ の分子吸収スペクトルはコバルトの原子吸光 測定 $(240.7 \mathrm{~nm})$ で大きな吸収干涉を与える，一方，鉄 は原子線の数が多く他の元素の原子吸収線と重なること が多い。そのため鉄の濃度が高い時分子吸収による干涉 のみならず線スペクトルの重なりによる干涉も生じる. Table I に亜鉛, カドミウム, ニッケル, マンガン, 銅，クロムの分析波長と近接する鉄の原子線を示した. 又, Table II に鉄 $10 \mathrm{mg} / \mathrm{ml}$ が共存する時のそれぞれ の元素に対する干涉誤差農度を示した。すべてが近接線 スペクトルのみによる干涉とは限らないが鉄による干涉 は原子吸光分析による亜鉛の測定感度の 17 倍，カドミウ
ムの 13 倍, ニッケルの 12 倍, マンガンの 5 倍, 銅の 4 倍, クロムの 7 倍程度であった. ベリリウム，セリウム， ラ ンタン，白金が共存する時の干涉誤差についても Table エに示したが，干涉誤差は少なくない。

\section{5. 結言}

ベリリウム，セリウム，ランタン，白金，鉄の水溶液 を空気ーアセチレン炎中に噴霧し炎中で生成した化合物 による分子吸収スペクトル，発光スペクトルを測定し， どのような化合物によるスペクトルかを調べた，不明な スペクトルについては今後明確にしていきたい. 又, こ 
れらの吸収スペクトルによる干涉誤差は分析值の正確さ を支配する程大きく，これらの金属塩を主成分とする時 の原子吸光分析におけるバックグランド補正に対する参 考となるであろう。

終わりに本実験に援助をいただいた本研究所分析室長 田村泟平助教授に感謝します.

\section{文献}

1) 大道寺英弘：分光研究 27, 360 (1978).

2) N. Furuta, E. Yoshimura, H. Haraguchi and K. Fuwa: Spectrochim. Acta, 33B, 715 (1978).

3) 大道寺英弘：分化 28, 77 (1979).

4) 原口紘点, 吉田直紀, 吉村悦郎, 不破敬一郎: 分化 24, 733 (1975).

5) 大道寺英弘：分光研究 27, 368 (1978).

6) S.R. Ko1rtyohann and E.E. Picket: Anal. Chem. 38, 585 (1966).

7) L.C. Delgado and S. Spragne: Atomic Absorption Newsletter, 4, 363 (1965).

8) A.M. Ure and R.L. Michell: Spectrochim. Acta, 23B, 79 (1967).

9) 大道寺英弘：分光研究 28,145 (1979).

10）大道寺英弘：分光研究 28,153 (1979).

11) H. Haraguch1, N. Furuta, E. Yoshimura and K. Fuwa: Anal. Chem. 48, 2066 (1976).

12) K. Tsunoda, K. Fujiwara and K. Fuwa: Anal. Chem. 50, 861 (1978).

13) K. Tsunoda, K. Fujiwara and K. Fuwa: Anal. Chem. 49, 2035 (1977).

14) 大道寺英弘：分光研究, 29,321 (1980).

15）大道寺英弘：分化, 29,389 (1980).

16) T. Nakahara and M. Musha: Anal. Chim. Acta, 80, 47 (1975).

17) H. Haraguchi and K. Fuwa: Spectrochim. Acta, 30B, 535 (1975).

18) H. Haraguchi and K. Fuwa: Anal. Chem. 48, 785 (1976).

19) H. Haraguchi, W.F. Fowler, D. J. Jonson and J.D. Winefordner: Spectrochim. Acta, 32B, 1539 (1976).

20）大道寺英弘，赤井義朗，本間厚：分光研究 28,77 (1979).

21) 大道寺英弘：分化, 29, 552 (1980).

22) 大道寺英弘：分化 29, 64 (1980).

23) 大道寺英弘：分化 投稿中

24) J.E. Rosenthal and F.A. Jenkins: Phys. Rev. 33, 163 (1929).
25) A. Harvey, F. Inst and H. Bell: Proc. Phys. Soc. 47, 415 (1935).

26) M. M. Novikov and L.N. Tuuitskii: Opt. Spectros. 18, 396 (1960).

27) R.W.B. Pearse and A.G. Gaydon: "The identification of molecular spectra" (Chapman and Hall, London, 1976) p. 70.

28) W.A. Chupka, J. Berkowitz and C.F. Grese: J. Chem. Phys. 30, 827 (1959).

29) D. H. Cotton and D. R. Jenkins: Trans. Faraday Soc. 67, 730 (1971).

30) R. Kelley and P.J. Padley: Trans. Faraday Soc. 67, 1384 (1971).

31) D. H. Cotton and D. R. Jenkins: Trans. Faraday Soc. 64, 2988 (1968).

32) D. S. Smyly, W. P. Townsent, P. J. T. Zeegers and J.D. Winefordner: Spectrochim. Acta, 26B, 531 (1971).

33) D. J. Halls: Spectrochim. Acta, 32B, 221 (1977).

34) D. Jensen and G.A. Jones: J. Chem. Soc. 68, 259 (1972).

35) C. A. Alexander, J.S. Ogden and A. Levy: J. Chem. Phys. 39, 3057 (1963).

36) J. O. Ramuson, V.A. Fassel and R. N. Kniseley : Spectrochim. Acta, 28B, 365 (1973).

37) L.DE Galan and G.F. Samaey: Spectrochim. Acta, 25B, 245 (1970).

38) E. M. Bulewicz, C. G. James and T.M. Sugden: Proc. Roy. Soc. 235A, 89 (1956).

39) W.W. Watson: Phys. Rev. 53, 639 (1938).

40) J.A. Fiorıno, R. N. Kniseley and V.A. Fassel : Spectrochim. Acta, 23B, 413 (1968).

41) V.A. Fassel, R.H. Curry and R.N. Kniseley: Spectrochim. Acta, 18, 1127 (1962).

42) P. N. Walsh, D.F. Dever and D. White: J. Phys. Chem. 65, 1410 (1961).

43) P. N. Walsh, H. W. Goldstein and D. White: Am. Ceramic Soc. 43, 229 (1960).

44) L. Brewer: Chem. Rev. 52, 38 (1953).

45) T. C. Rains, H.P. House and O. Menis: Anal. Chim. Acta, 22, 315 (1960).

46) W.A. Chupka, M. G. Inghram and R.F. Porter : J. Chem. Phys. 24, 792 (1956).

47) B. Kaving and R. Scullman: Can. J. Phys. 49, 2264 (1971).

48) C. Nilsson, R. Scullman and N. Mehendale: J. Mol. Spectros. 35, 172 (1970).

49) A. B. Callear and R.G. Norrish: Proc. Roy. Soc. 259, 304 (1960). 